This document is

PUBLICLY RELEASABLE

Xkele Linees

Authoring Oiicial

Date: $3 \sqrt{2}, 0$

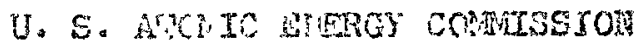

new youspick Iaburatory

Jen 3runswiek, th Jeriey

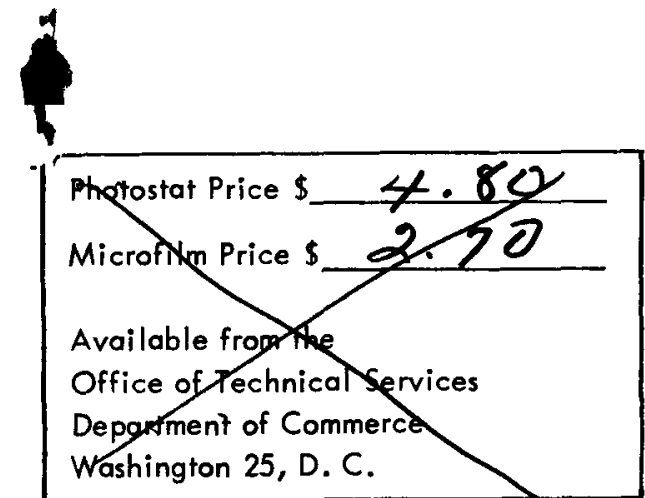

$$
\text { i }
$$

By

Hearold R. Ruluin Spectrochomical Branch

$\operatorname{and}$

Josewh J. 'Pxergoning coneral analyitcal Erench

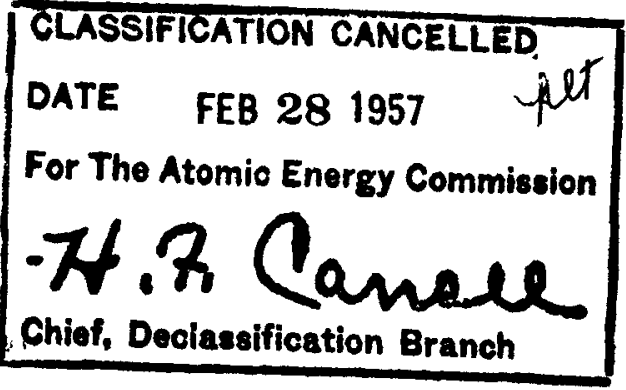

Chiof, Declassification Branch

\title{
AUG 131952
}

\section{LEGAL NOTICE}

This report was prepared as on account of Government sponsored work. Neither the United States, nor the Commission, nor any parson acting on behalf of the Commission:

A. Makes any warranty or representation, express or implied, with respect to the accuracy, completeness, or usefulness of the information contained in this report, or that the use of any information, apparatus, method, or process disclosed in this report may not infringe privately owned rights; or

B. Assumes any liabilities with respect to the use of, or for damages resulting from the use of any information, apparatus, method, or process disclosed in this report.

As used in the above, "person acting on behalf of the Commission" includes any employee or contractor of the Commission to the extent that such employee or contractor prepares, handles or distributes, or provides access to, any information pursuant to his employment or contract with the Commission. 


\section{DISCLAIMER}

This report was prepared as an account of work sponsored by an agency of the United States Government. Neither the United States Government nor any agency Thereof, nor any of their employees, makes any warranty, express or implied, or assumes any legal liability or responsibility for the accuracy, completeness, or usefulness of any information, apparatus, product, or process disclosed, or represents that its use would not infringe privately owned rights. Reference herein to any specific commercial product, process, or service by trade name, trademark, manufacturer, or otherwise does not necessarily constitute or imply its endorsement, recommendation, or favoring by the United States Government or any agency thereof. The views and opinions of authors expressed herein do not necessarily state or reflect those of the United States Government or any agency thereof. 


\section{DISCLAIMER}

Portions of this document may be illegible in electronic image products. Images are produced from the best available original document. 

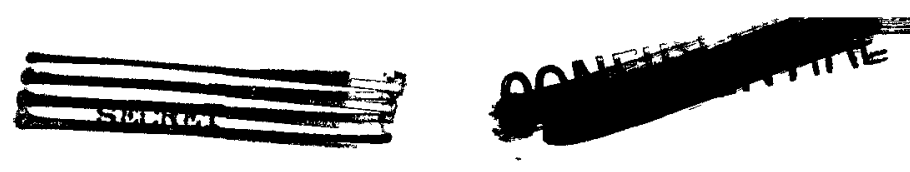

PRELTMIIMARY REPORT ON AWALYSIS OF THORIUM METAL

Introduction

The analysis of thorium metal is of interest to many laboratories in both the producer and the consumer field.

As of this date, the methods and the results may vary to the extent of the number of laboratories doing the analysis. Some knowledge of the analysis must be had in order to establish confidence in the purity of the metal.

It is the purpose of this paper to list the several methods now employed with some correlation of the accuracy that may be expected in the results.

The specifications for the impurity content of the hetal have been 11ttie changed in the past two years. The tentative specifications as supplled for the Waterials Testine Reactor are as follows:

\begin{tabular}{|c|c|c|c|}
\hline Element & ppm & Element & ppra \\
\hline C & 1000 & $\mathrm{MF}$ & Prace \\
\hline 0 & 500 & $\mathrm{Zn}$ & Trace \\
\hline $\mathbf{N}$ & 100 & $\mathrm{Ce}$ & 15 \\
\hline A.1 & 100 & La & 5 \\
\hline $\mathrm{Fe}$ & 300 & INa & 2 \\
\hline $\mathrm{Be}$ & 1000 & $D_{y}$ & 0.05 \\
\hline $\mathrm{U}$ & 5 & $\mathrm{Px}$ & 0.4 \\
\hline $\mathrm{Ca}$ & Trace & $S m$ & 0.1 \\
\hline N1 & Trace & $Y$ & 0.05 \\
\hline S1 & Trace & Ga & 0.2 \\
\hline
\end{tabular}

The above speciflcation does not include all the elements that are probably present. Since a more complete analysis may be desired in the future, there has been additional work cone on the determination of other elements. 

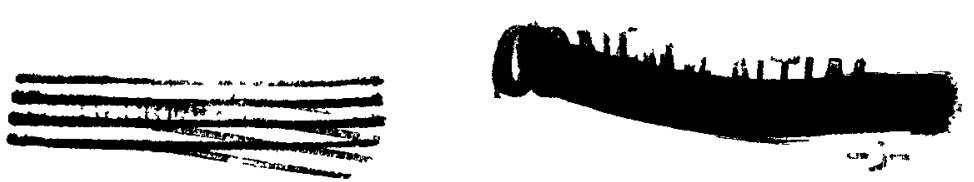

There has not been a groat deal of correlation data obtained as yet on tho.lun samples. The metaidurgical laboratory at Ames, Iora, has made several lots of thorium netal vith reat care to guard against contanination and segregation. Iriplicate portions of the sannles vere talren and analyzed by both the Ames Laboratory and the Nev Brunswick Laboratory.

From a spectrographie standpoint and considering that many of the NBI values vere visual estimations, the arreement in the results was quite satisfactory for the elenents determined. There is insufficlent data at this time for aatisfactory comparison of chemical results.

In addition to the pure metals prepared, there have been sevarai lots of impure metal on which both Ames and NBL have nade analysis. Compliation of the data are shown in Tables I and II at the end of this report. 


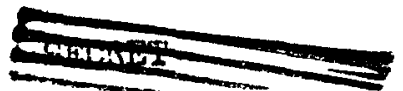

CHEMICAL FROCEDLRES

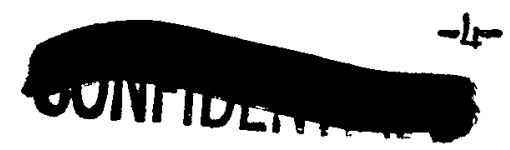

\section{Carbon}

BMI - A combustion procedure for the determination of carbon is used at the Battelle Memorlel Inst1tute.

NBL - A combustion procedure similar to that used for the detexmination of carbon in uranium is used at NBL.

AMES - A report inaicates difficulty is exporienced in the determination of carbon in thorium by their combustion method.

\section{M1trogen}

BMI - The Kjeldahl nethod for determination of nitrogen is used. IBL - A micro-kjeldahl method similar to that used for nitrogen in uranium is used at NBL.

\section{Oxygen}

BMI - Oxygen is determined by a vacuum fusion teshnique. A thorium sample $(0.2-0.5 \mathrm{~cm})$ is dissolved in an outgassed tin bath (5-20 gms) contained in a graphite cruciole. Using an operating temperature of $3200^{\circ} \mathrm{F}$, the oxygen content of the specimen is extracted as carbon monoxide. arygen results are repeatable on duplicate specimens to $\$ 5$ to 10 percent of the obtained values.

NBI - Combined oxygen in thoriun metal is determined by dissoiving' the metal in oxygen free $6 \mathrm{~N} \mathrm{HCl.} \mathrm{The} \mathrm{insoluble} \mathrm{material} \mathrm{is} \mathrm{ignited,}$ welghed, and reported as HCl insoluble.
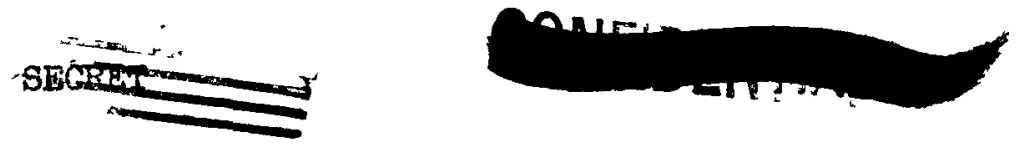
HIDROGEN

BIII - The tin fusion method for hydrogen in thorlum appears to give better results than coes the vacuum fusion. This method consists of dissolving the sample in a large bath of tin (100 grms) contained in a carbon free furnace assembly. The operating temperature is $1000^{\circ} \mathrm{C}$. The gas extraction is usually complete rithin 15 minutes. Practically all the gas evolved appears to be hydrogen.

BBI - Hydrogen has not been determined in any of the samples of thorium metal.

MANGANESE

NBL - The manganese is cetermined in a nitrate solution of the thorium metal by adding a weighed amount of potassium lodate, developing the color, and reading the transmittancy in a spectrophotometer.

IRON

NBI - The iron in thorium metal is determined on the nitrate solution by a method similar to that used for uranium. Solutions of ortho-phenanthroline and hydroxylamine hydrochloride are added, the $\mathrm{pH}$ adjusted and the transmittancy of the solution measured in a spectrophotometer. URANIUR!

AIES - The reclaimed thorium metal is analyzed for uranium by extracting the uranium with diethyl ether and then measuring the absorbency of the thiocyanate complex. This method seems to be good to $\pm 0.5 \mathrm{ppm}$ of urantum in thorium. 
NBL - Thorium metal is converted to the nitrate, the uranium is extracted from the nitrate solution with TBP. The TBP is stripped by carbonate solution. After destruction of the carbonate, the uranium is determined polerographically.

\section{RARE EARTI}

NDI - A $50 \mathrm{~g}$. sample of metal is dissolved in nitric acid and the sample is evaporated to dryness. The dried sample, thorium nitrate, is treated with tributyl phosphate which extracts the bulk of the thorium nitrate. The aqueous layer, which is saturated with thorium nitrate also contains the rare earth nitrates, is diluted with water; the thorium is separated from the rare earth by repeated precipitations with hexamine solution $(5, j)$. Finally the rare earths are precipitated with oxalic acid and the precipitate is collected and ignited to the oxide.

BII - A $50 \mathrm{~g}$. sample of metal is dissolved in nitric acid and the sarmple is evaporated to dryness. The dried sample, thorium nitrate, is dissolved in $2 \mathrm{~N}$ nitric acid and treated with cellulose powder. The sample is repeatedly treated with ether-nitric acid (200-25) and the portion of the solution is passed through a prepared cellulose column. The column is then eluted with $2 \mathbb{N}$ nitric acid. The elute is evaporated to a small volume and the acidity is adjusted and a repeat of the above treatment with cellulose, ether-nitric acid, and the column passing is made.

The elute from the second treatment is evaporated to dryness and any organic matter is decomposed by the addition of nitric acid.
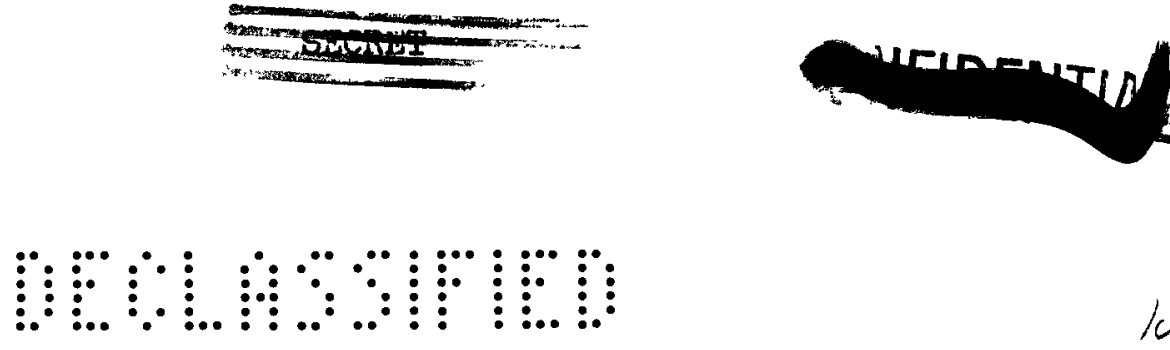


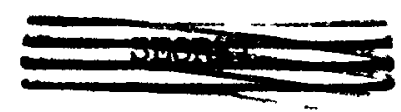

SPECTROGRAPHTC PROCEDURE

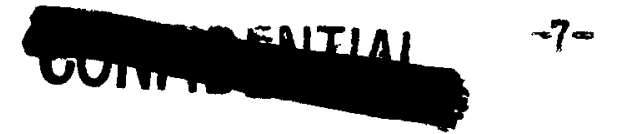

Spectrographic procechures have been the methods generaly emiloyed for the cetection of the metallic elenents in the analysis of churium samples.

Since the thorium spectrum is quite cormplex and the material is of a refractory nature there is no present procedure employing a direct examination for impurity content. Each laboratory engaged in the analysis of thorium metal has employed those procedures which they have generally found to be satisfactory for refractory materials.

ARES

The ines procedure called for the simultineous deternination of $A 1$, $\mathrm{Fe}$, IG, $\mathrm{Ca}_{2}, \mathrm{Si}, \mathrm{B}, \mathrm{C}_{\mathrm{d}}, \mathrm{Zn}$, and $\mathrm{Be}$. The metal oxide is mixed with powdered flake graphite in the ratio $1: 2$ and compressed into $1 / 4$ inch diameter conducting pellets by application of high pressure. These pellets are excited by means of a 60 cycle, 960 volt overdamped concenser discharge. Preliminary results incicate that all resicual metallic impurities of interest except fractional parts per million quantities of boron, cadmium, and the rare earths can be determined in this manner.

MBL

The spectrochemical procecture used for the analysis of thorium samples at the New Brunswick Laboratory follows identically the procedure for the analysis of uranium. This procedure is described in detail in report A-2907. This method can be used for the determination of $\mathrm{Ag}, \mathrm{Al}, \mathrm{As}, \mathrm{B}, \mathrm{Bi}, \mathrm{Ca}, \mathrm{CC}$, $\mathrm{Co}, \mathrm{Cr}, \mathrm{Cu}_{\mathrm{u}}, \mathrm{Fe}, \mathrm{Ge}$, In, II, $\mathrm{ilg}, \mathrm{In}, \mathrm{Ho}, \mathrm{Na}_{\mathrm{a}} \mathrm{Nj}, \mathrm{P}, \mathrm{Ib}, \mathrm{Sb}, \mathrm{Si}, \mathrm{Sn}, \mathrm{V}$ and in.
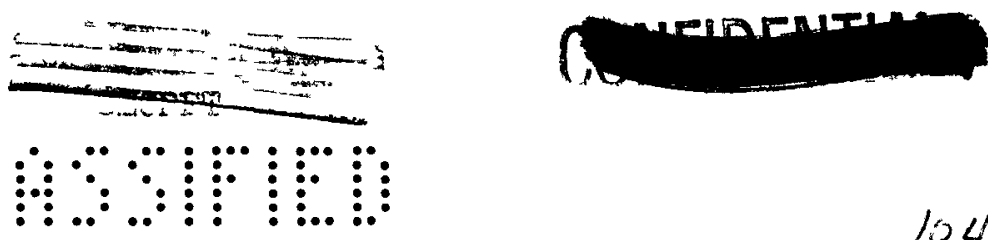
This is a carrier-distillation procecure using $\mathrm{Ga}_{2} \mathrm{O}_{3}$ in the amount of $2 ;$ of the sample weight as the carrier. The sample mixture is excited In a 10 amp $250 \mathrm{~V}$ d.c. arc where the sample impurities distill from the sample into the arc stream. Estimations of the amount of Impurity present are made by visually comparing the spectrum of the sample against the spectra of standards run under the same conditions. By standard densitometric procedures it is possible to make more precise determinations when desirable.

The spectrographic analysis of the rare earth concentrates is only a qualitative report at this time. Since rare earth concentrates as prepared from thorium samples are generally cerium-lanthanum mixtures, it is not felt that the samples would corapare at all favorably with standards that are of a yttrium matrix. Work is progressing on development of a procedure for the analysis of Ce-La matrix.

BMII

The Battelle Memorial Institute uses a very similar procedure employing $\mathrm{AgCl}$, instead of $\mathrm{Ga}_{2} \mathrm{O}_{3}$ as the carrier additive.

In the BMI procecure for rare earths the resulting solution after the organic material decomposition is further treated by the addition of palladium solution for the internal standard and then adjusting the final volume with $1: 1$ nitric acid and so that $0.6 \mathrm{ml}$ is equivalent to $10 \mathrm{~g}$ of thorium.

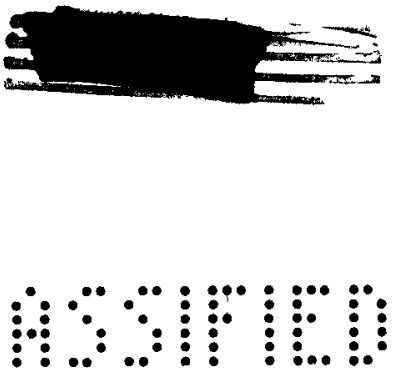


The solution is placed on counter electrodes in the excitation stand using a $3 \mathrm{~mm}$ gap spacing. Oxygen is passed through the atmosphere chamber surrounding the electrodes for 30 seconds before starting the spark. The samples are then excited in the high-voltage spark using $4 / 3$ kva capacitance, $0.32 \mathrm{mh}$ incuctance and 45 second exposure. Densitometric measurements are made of the impurity lines.

\section{REFERENCES}

AII results and procecures in the report were obtained from the following references.

The Technology of Thorium, BrI-76

The Determination of Rare Earths in Thorium, BMI-260

Semi-inmual irogress Report in Chemistry - Apr11 1 - September 30, 1951, ISC-184

Zuarterly Summary Research Report, Oct., Nov., and Dec. 1951, ISC-220

Communication, V. A. Fassel to H. R. Hullin, Ilay 9, 1952.

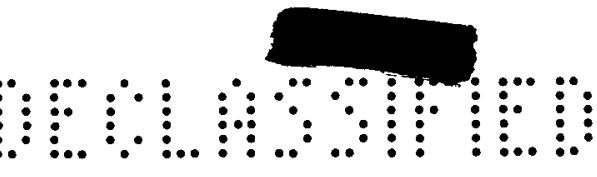


COMPARISON OF REGULTS FROM

NEW BRUASWICK IAAORATORY AND AMTS IABORATORY

ON THORIUM METAZ SAMPIES

TABLE I.

TRIPLICATE PORTIONS FROM SAME INGOT 


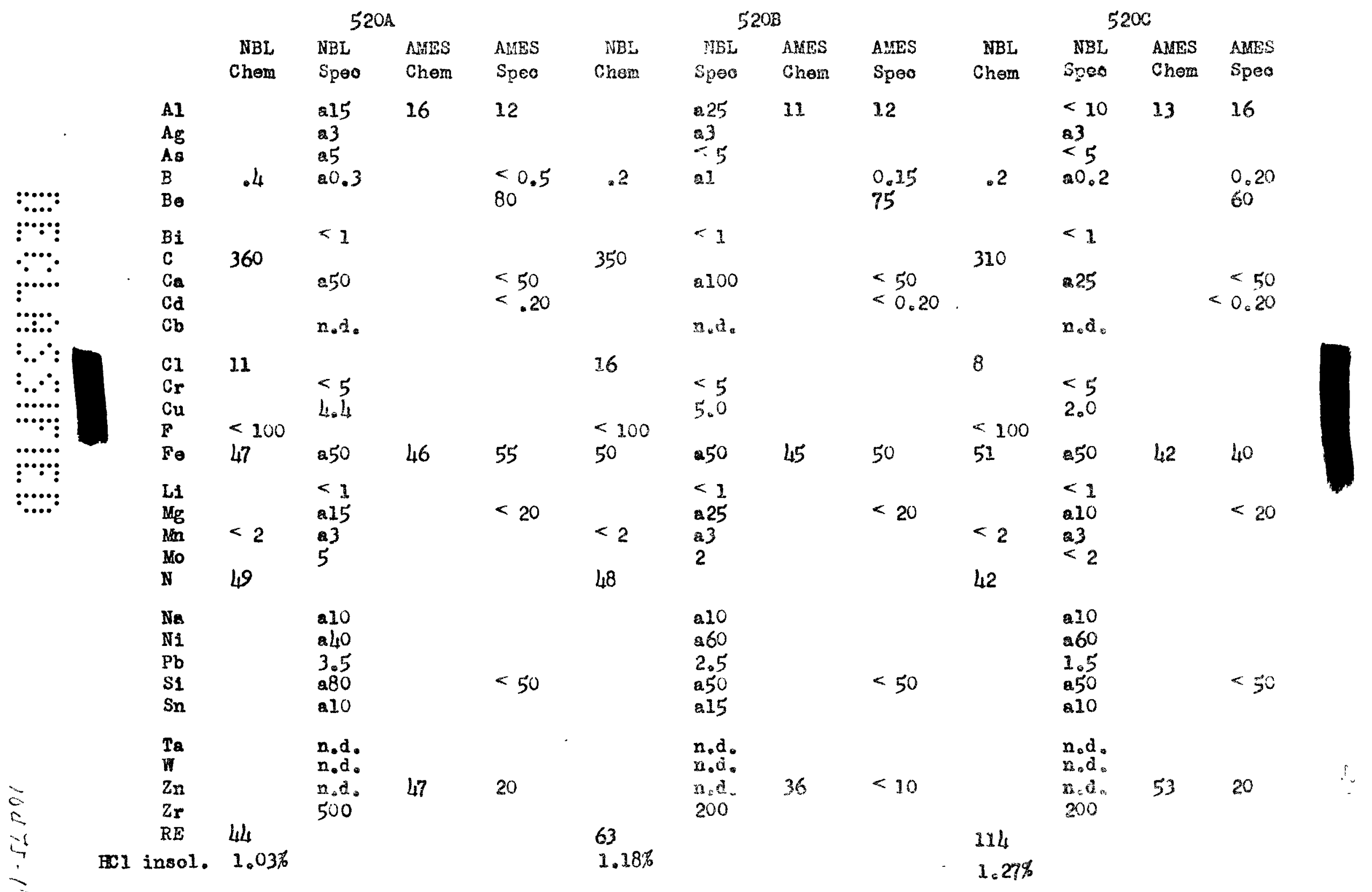




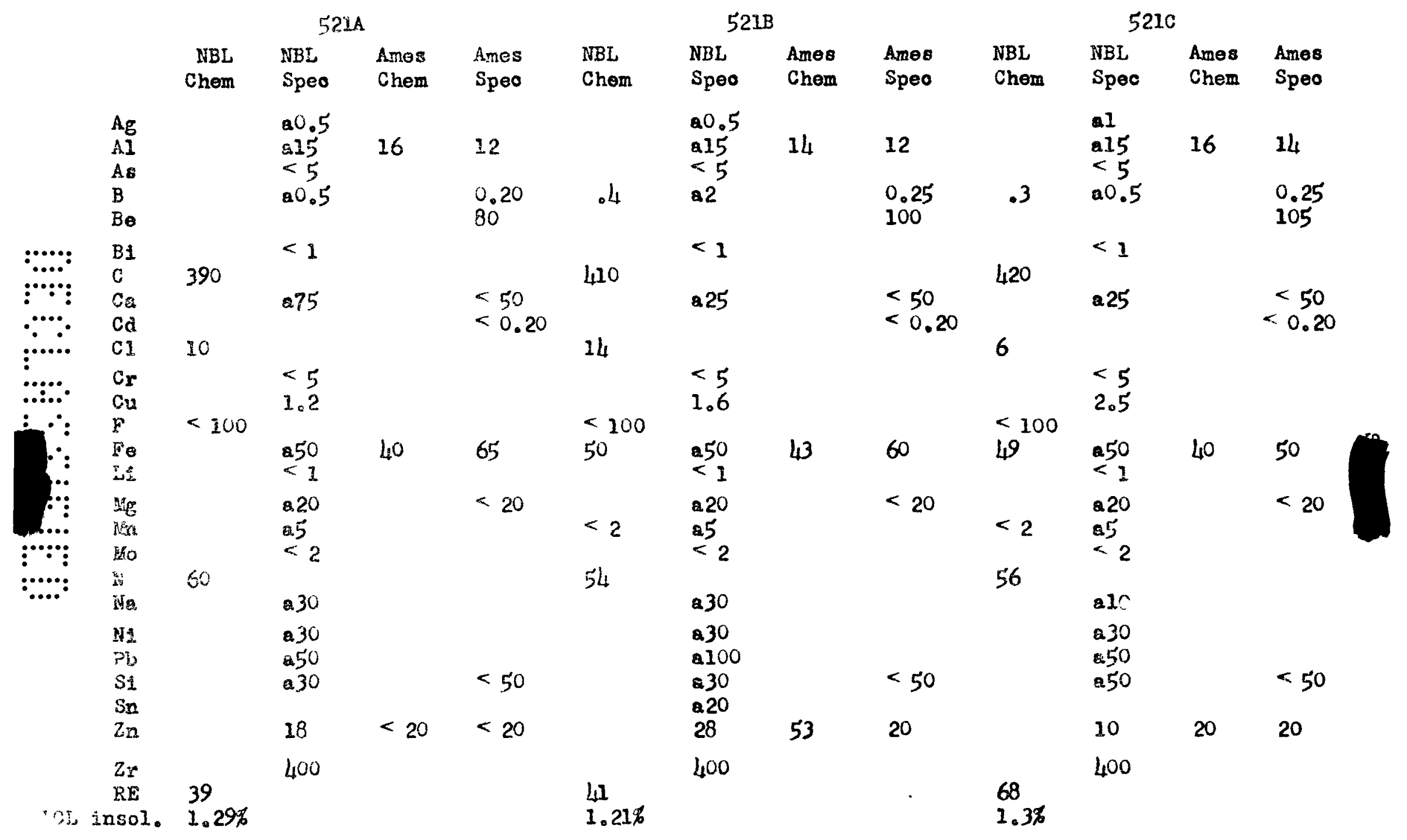




$$
13
$$

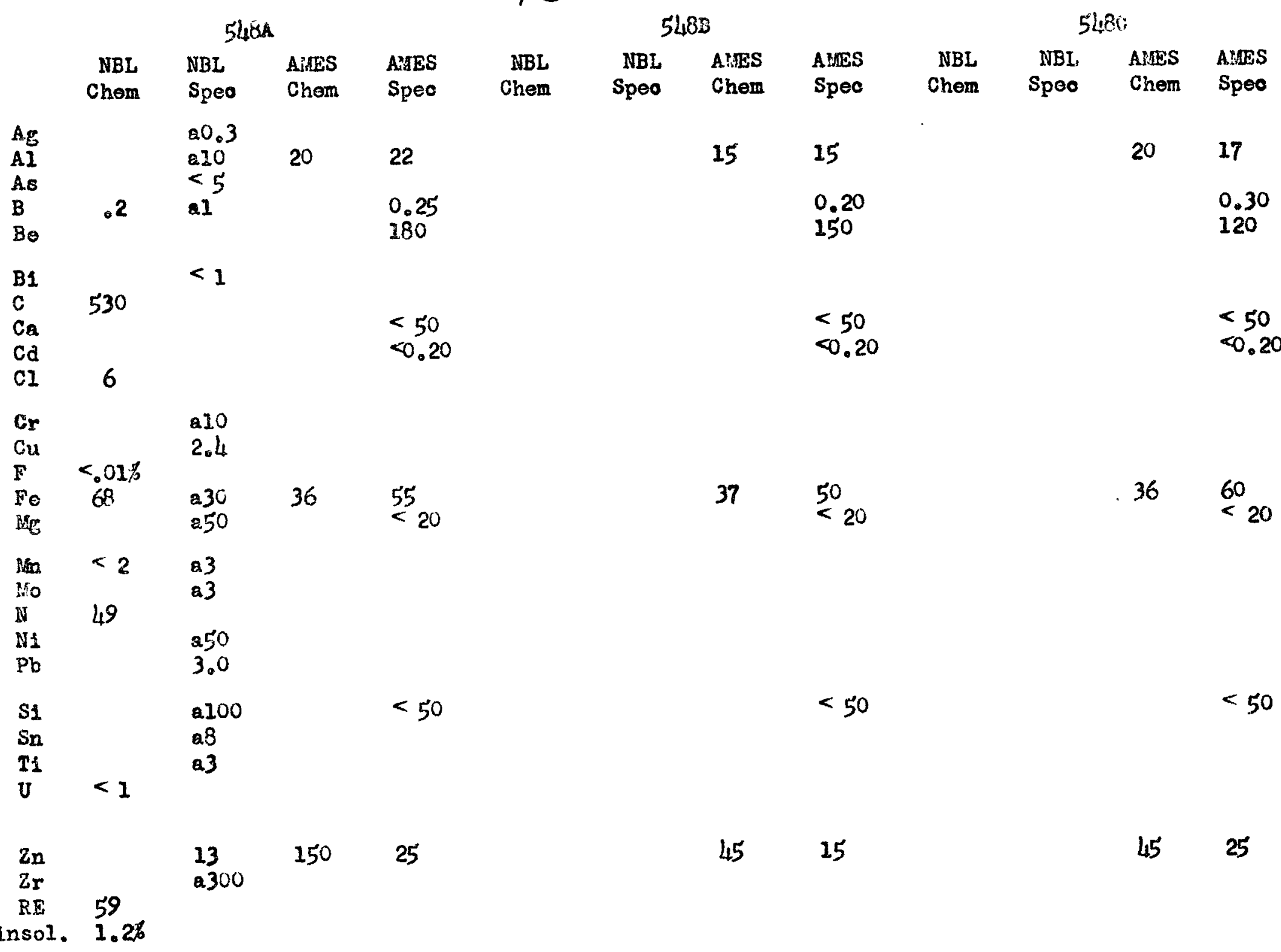


COMPARISON OF RLSULIS FROM

ILWW BRUHSWICK INECRATORY AND AMES LABORATORY

ON THORIUM METAL SAMPLES

TABIE II.

ROUTINE RICAST THORIUM METAL

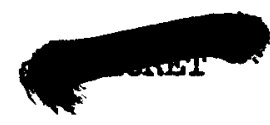




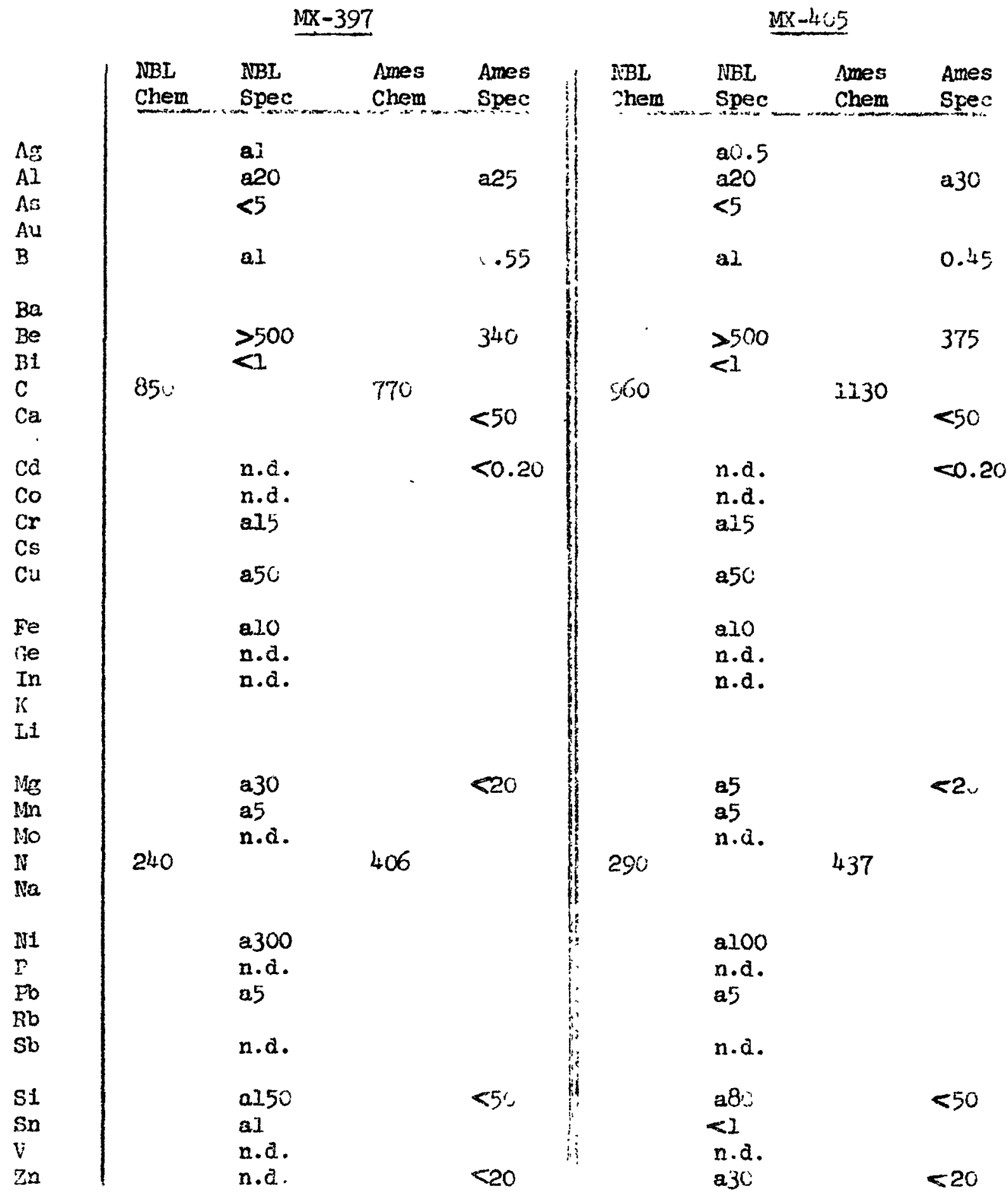




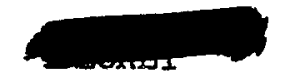

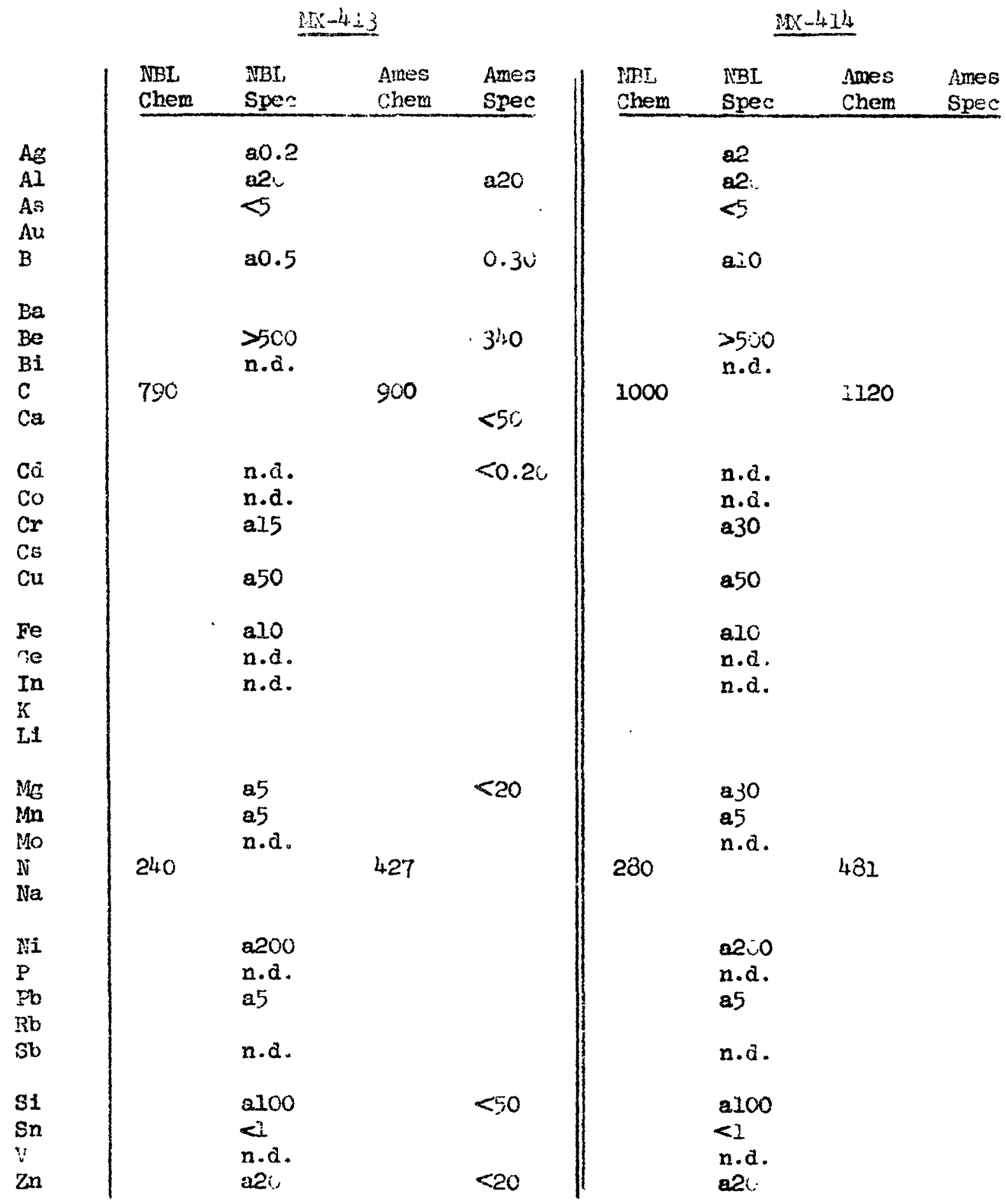

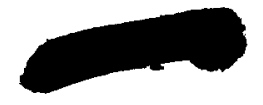


$3 x-415$

$3 X-425$

\begin{tabular}{|c|c|c|c|c|c|c|c|c|}
\hline & $\begin{array}{l}\text { NBL } \\
\text { Chem }\end{array}$ & $\begin{array}{l}\text { NBL } \\
\text { Spec }\end{array}$ & $\begin{array}{l}\text { Anes: } \\
\text { Chom }\end{array}$ & $\begin{array}{l}\text { Ames } \\
\text { Spe: }\end{array}$ & $\begin{array}{l}\text { NBI, } \\
\text { chem }\end{array}$ & $\begin{array}{l}\text { SBL } \\
\text { Spec }\end{array}$ & $\begin{array}{l}\text { Ames } \\
\text { Chem }\end{array}$ & $\begin{array}{l}\text { Ames } \\
\text { Spec }\end{array}$ \\
\hline $\begin{array}{l}\mathrm{Ar} \\
\mathrm{AI} \\
\text { As } \\
\mathrm{Au} \\
\mathrm{B}\end{array}$ & & $\begin{array}{l}a 1 \\
020 \\
<5 \\
02\end{array}$ & & & & $\begin{array}{l}a 2 \\
a 20 \\
=5 \\
a 2\end{array}$ & & \\
\hline $\begin{array}{l}\mathrm{Ba} \\
\mathrm{Be} \\
\mathrm{BI}\end{array}$ & & $\begin{array}{l}>500 \\
\text { a. }\end{array}$ & & & & $\begin{array}{l}>500 \\
<1\end{array}$ & & \\
\hline $\begin{array}{l}\mathrm{C} \\
\mathrm{Ca}\end{array}$ & 840 & & 2355 & & 830 & & 805 & \\
\hline $\begin{array}{l}\mathrm{Cd} \\
\mathrm{Co} \\
\mathrm{Cr} \\
\mathrm{Cs} \\
\mathrm{Cu}\end{array}$ & & $\begin{array}{l}\text { n.d. } \\
\text { n.d. } \\
\text { a30 } \\
250\end{array}$ & & & & $\begin{array}{l}\text { n.a. } \\
\text { n.d. } \\
\text { a.30 } \\
250\end{array}$ & & \\
\hline $\begin{array}{l}\text { Fe } \\
\text { Se } \\
\text { In } \\
\mathrm{K} \\
\mathrm{II}\end{array}$ & & $\begin{array}{l}2.10 \\
\text { n.d. } \\
\text { n.d. }\end{array}$ & & & & $\begin{array}{l}\text { alo } \\
\text { n.d. } \\
\text { n.d. }\end{array}$ & & \\
\hline $\begin{array}{l}\text { Mg } \\
\text { Mn } \\
\text { Mo } \\
\text { N }\end{array}$ & 320 & $\begin{array}{l}\text { alo } \\
\text { a5 } \\
\text { n.d. }\end{array}$ & 560 & & 270 & $\begin{array}{l}\text { alo } \\
\text { a5 } \\
\text { n.d. }\end{array}$ & 318 & \\
\hline $\begin{array}{l}\mathrm{Ni} \\
\mathrm{P} \\
\mathrm{Pb} \\
\mathrm{Rb} \\
\mathrm{Sb}\end{array}$ & & $\begin{array}{l}23 c 0 \\
\text { n.d. } \\
\text { a5 } \\
\text { n.d. }\end{array}$ & & & & $\begin{array}{l}\text { a.50 } \\
\text { n.d. } \\
\text { a.5 } \\
\text { n.d. }\end{array}$ & & \\
\hline $\begin{array}{l}\text { Si } \\
\text { Sn } \\
\text { y } \\
\mathrm{Zn}\end{array}$ & & $\begin{array}{l}a 100 \\
a 2 \\
\text { n.d. } \\
<20\end{array}$ & & & & $\begin{array}{l}2100 \\
<1 \\
\text { n. } \\
<0\end{array}$ & & \\
\hline
\end{tabular}




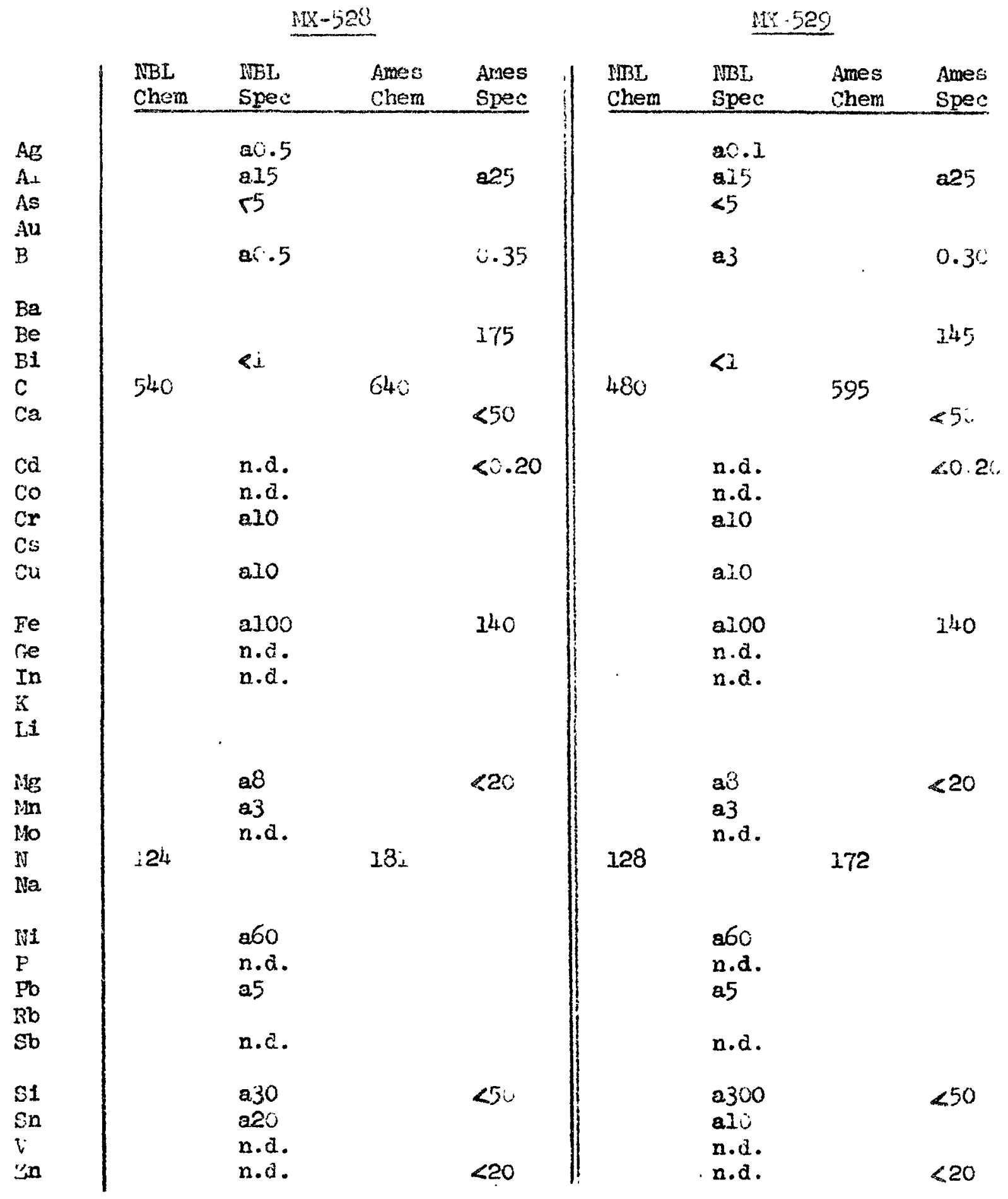




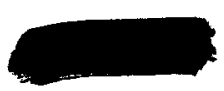

\section{2x- $-53 i$}

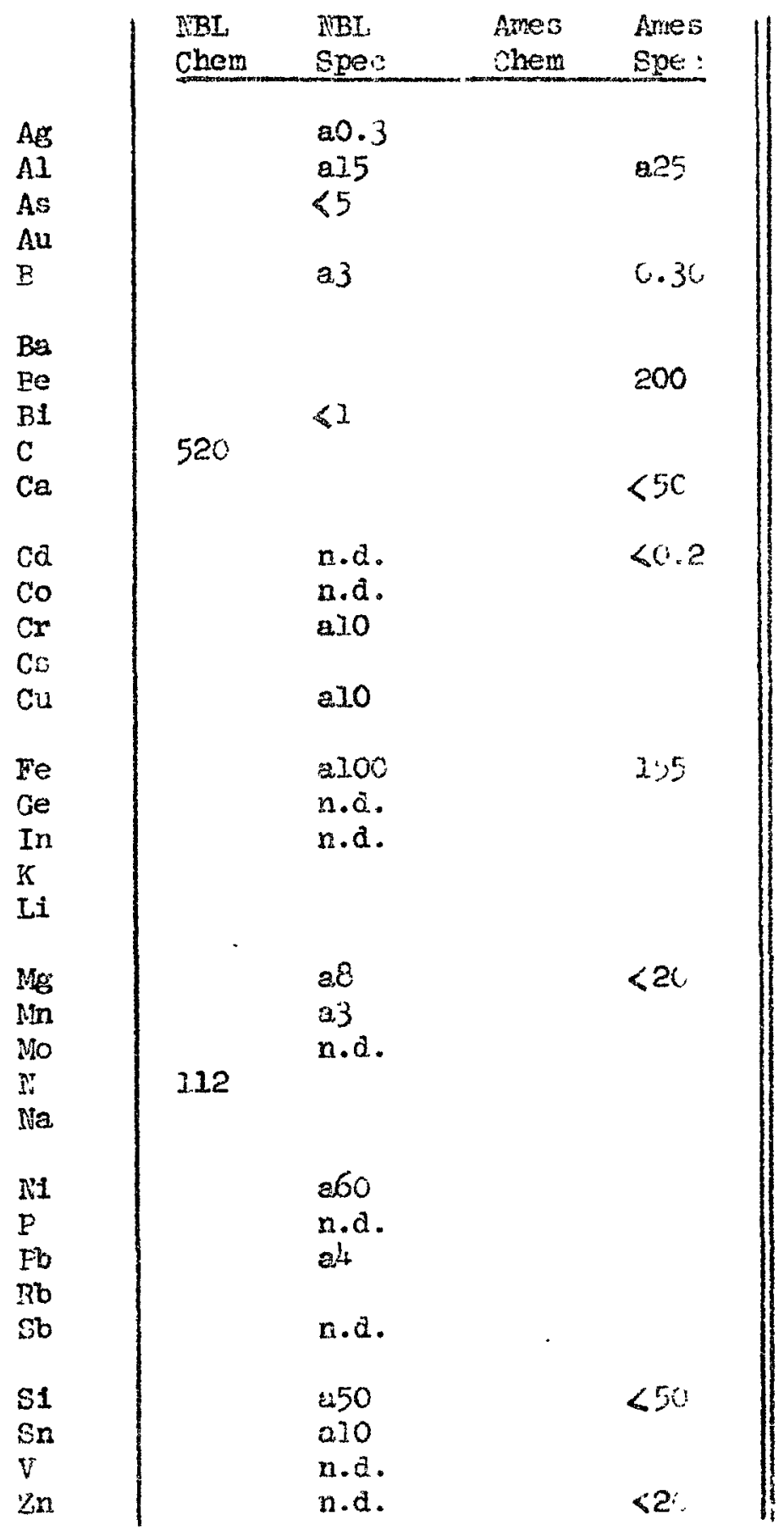

700

\begin{tabular}{|c|c|c|c|}
\hline $\begin{array}{l}\text { nisL } \\
\text { chem }\end{array}$ & $\begin{array}{l}\text { INIL } \\
\text { Spec }\end{array}$ & $\begin{array}{l}\text { Ames } \\
\text { hem }\end{array}$ & \\
\hline & $\begin{array}{l}20.3 \\
250 \\
<5\end{array}$ & & \\
\hline & $a i$ & & \\
\hline & $\begin{array}{l}>2000 \\
\text { n.a. }\end{array}$ & & \\
\hline
\end{tabular}

700

n.d.

$\therefore .2$

n.c.

alo

210

a.100

n.d.

3

n.d.

136

$$
\begin{aligned}
& 25 \\
& 22 \\
& \text { n.a. }
\end{aligned}
$$

a30
n.d.
a4
n.d.
a5co
n.d.
n.d.
n.a.


$1 x-573$

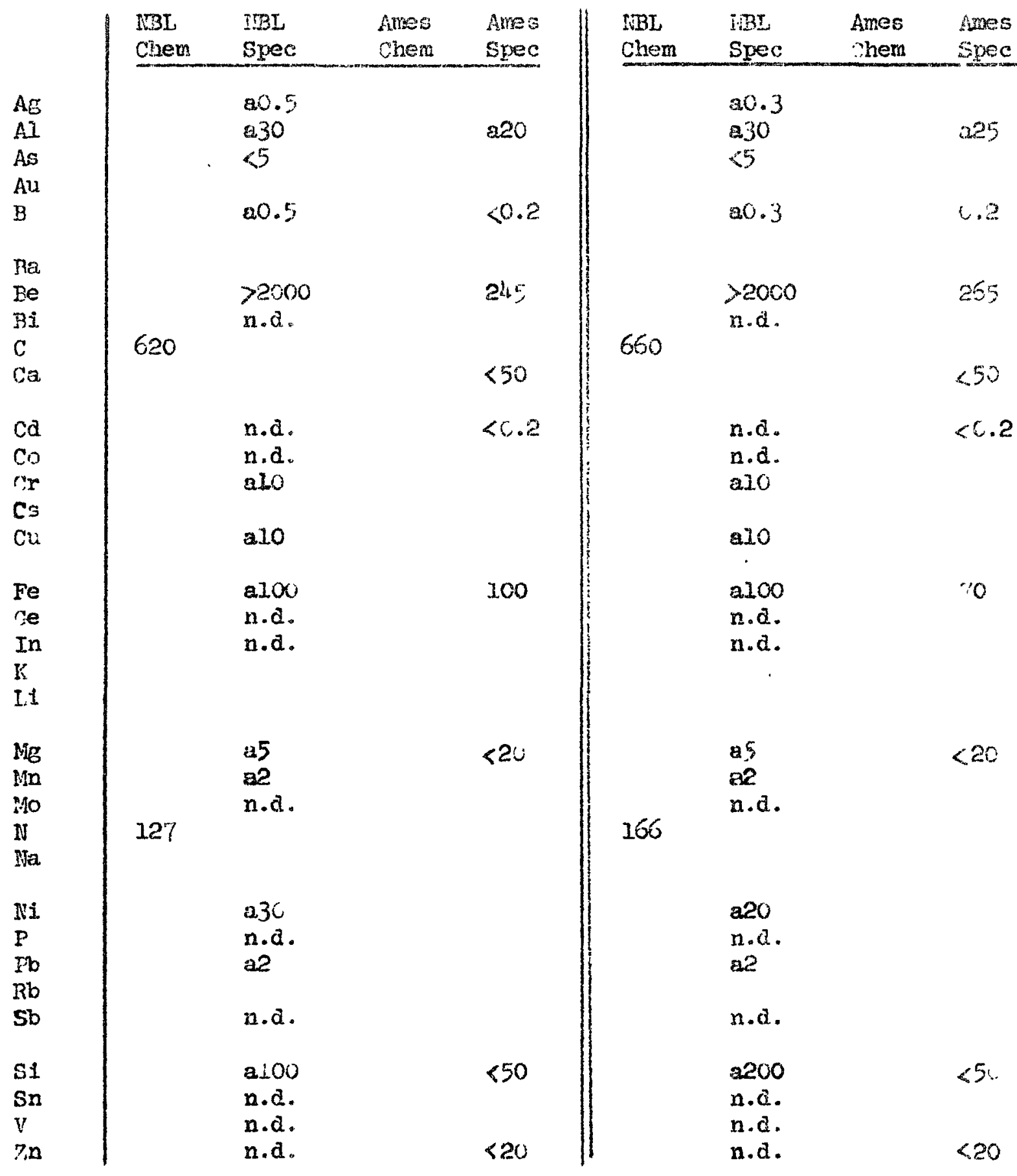

$M 3 \times-575$ 
$2 x-580$

M-582

\begin{tabular}{|c|c|c|c|c|c|c|c|c|}
\hline & $\begin{array}{l}\text { MBL } \\
\text { Chem }\end{array}$ & $\begin{array}{l}\text { INBI } \\
\text { Spec }\end{array}$ & $\begin{array}{l}\text { Ames } \\
\text { Chem }\end{array}$ & $\begin{array}{l}\text { Ames } \\
\text { Spee }\end{array}$ & $\begin{array}{l}\text { IBBL } \\
\text { Chem }\end{array}$ & $\begin{array}{l}\text { NBL } \\
\text { Spe:: }\end{array}$ & $\begin{array}{l}\text { Ames } \\
\text { Chem }\end{array}$ & $\begin{array}{l}\text { Ames } \\
\text { Spec }\end{array}$ \\
\hline $\begin{array}{l}A E \\
A I \\
A S \\
A u \\
B\end{array}$ & & $\begin{array}{l}20.2 \\
230 \\
<5 \\
80.5\end{array}$ & & & & $\begin{array}{l}\text { a.. } \\
\text { a. } 5 \\
<5 \\
\text { a. }\end{array}$ & & \\
\hline $\begin{array}{l}\mathrm{Ba} \\
\mathrm{Be} \\
\mathrm{BI} \\
\mathrm{C} \\
\mathrm{Ca}\end{array}$ & 620 & n.a. & 775 & & 530 & $<I$ & 610 & \\
\hline $\begin{array}{l}\mathrm{Cd} \\
\mathrm{Co} \\
\mathrm{cr} \\
\mathrm{cs} \\
\mathrm{cu}\end{array}$ & & $\begin{array}{l}\text { n.d. } \\
\text { n.d. } \\
\text { a.5 } \\
\text { a20 }\end{array}$ & & & & $\begin{array}{l}\text { n.d. } \\
\text { n.d. } \\
\text { al5 } \\
\text { a.15 }\end{array}$ & & \\
\hline $\begin{array}{l}\mathrm{Fe} \\
\mathrm{Ge} \\
\mathrm{In} \\
\mathrm{K} \\
\mathrm{LI}\end{array}$ & & $\begin{array}{l}\text { a.dod } \\
\text { n.d. } \\
\text { n.d. }\end{array}$ & & & & $\begin{array}{l}\text { alco } \\
\text { n.d. } \\
\text { n.d. }\end{array}$ & & \\
\hline $\begin{array}{l}\mathrm{Mg} \\
\mathrm{Mn} \\
\text { Mo }\end{array}$ & & $\begin{array}{l}0.15 \\
\text { a3 } \\
\text { n.d. }\end{array}$ & & & & $\begin{array}{l}\text { alo } \\
23 \\
\text { n.d. }\end{array}$ & & \\
\hline $\begin{array}{l}\mathrm{N} \\
\mathrm{Na}\end{array}$ & 150 & & 2نo & & 86 & & 135 & \\
\hline $\begin{array}{l}\mathrm{rid} \\
\mathrm{P} \\
\mathrm{Pb} \\
\mathrm{Rb} \\
\mathrm{Sb}\end{array}$ & & $\begin{array}{l}a 50 \\
\text { n.d. } \\
\text { a. } \\
\text { n.d. }\end{array}$ & & - & & $\begin{array}{l}\text { a.30 } \\
\text { n.d. } \\
\text { a4 } \\
\text { n.d. }\end{array}$ & & \\
\hline $\begin{array}{l}S 1 \\
\text { Sn } \\
v \\
z n\end{array}$ & & $\begin{array}{l}2500 \\
\text { a.d } \\
\text { n.d. } \\
\vdots 20\end{array}$ & & & & $\begin{array}{l}a 800 \\
\text { n.d. } \\
\text { n.d. } \\
\text { n.d. }\end{array}$ & & \\
\hline
\end{tabular}


$2 x-53$

$24-568$

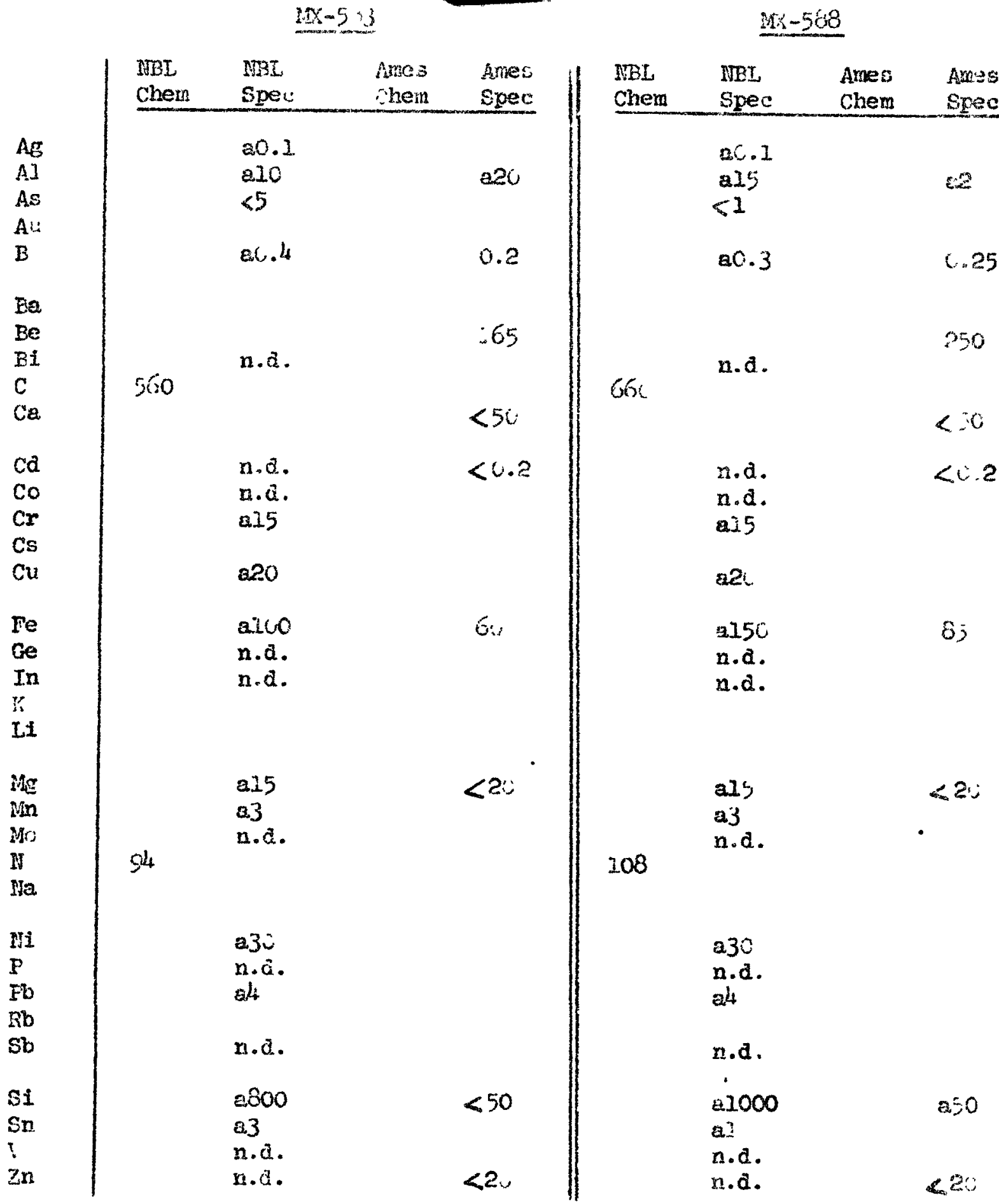

\section{ananmo}


Me -600

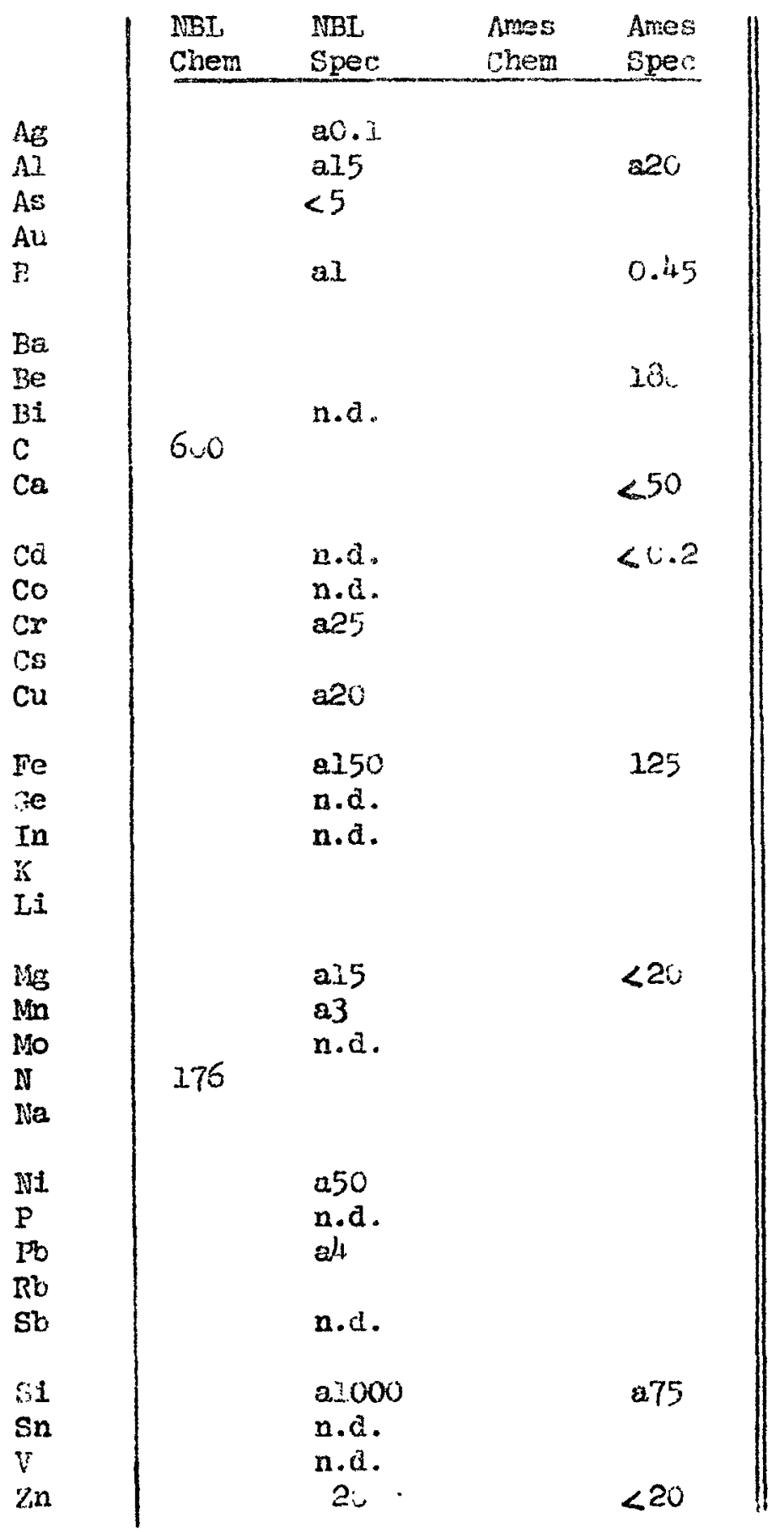

$M-6,3$

\begin{tabular}{|c|c|c|c|}
\hline $\begin{array}{l}\text { INBI } \\
\text { Chem }\end{array}$ & $\begin{array}{l}\text { NBI } \\
\text { Spec }\end{array}$ & $\begin{array}{l}\text { Ames } \\
\text { Chem }\end{array}$ & $\begin{array}{l}\text { Anes } \\
\text { Speec }\end{array}$ \\
\hline & $\begin{array}{l}a 0.1 \\
a 25 \\
<5\end{array}$ & & 220 \\
\hline & $a 0.5$ & & .3 \\
\hline & $\begin{array}{l}>2000 \\
<1\end{array}$ & & .25 \\
\hline & & & 650 \\
\hline & $\begin{array}{l}n . d . \\
\text { n.d. } \\
220\end{array}$ & & $\angle C, 2$ \\
\hline & 210 & & \\
\hline & $\begin{array}{l}2.200 \\
\text { n.d. } \\
\text { n.d. }\end{array}$ & & 125 \\
\hline & $\begin{array}{l}\text { alo } \\
\text { a3 }\end{array}$ & & $<20$ \\
\hline
\end{tabular}

276
350

n. 2.

a)

n.d.

a1000

n.d.

n.a.

n. $a$. a.

$<20$ 
$1 x-627$

$19 x-621$

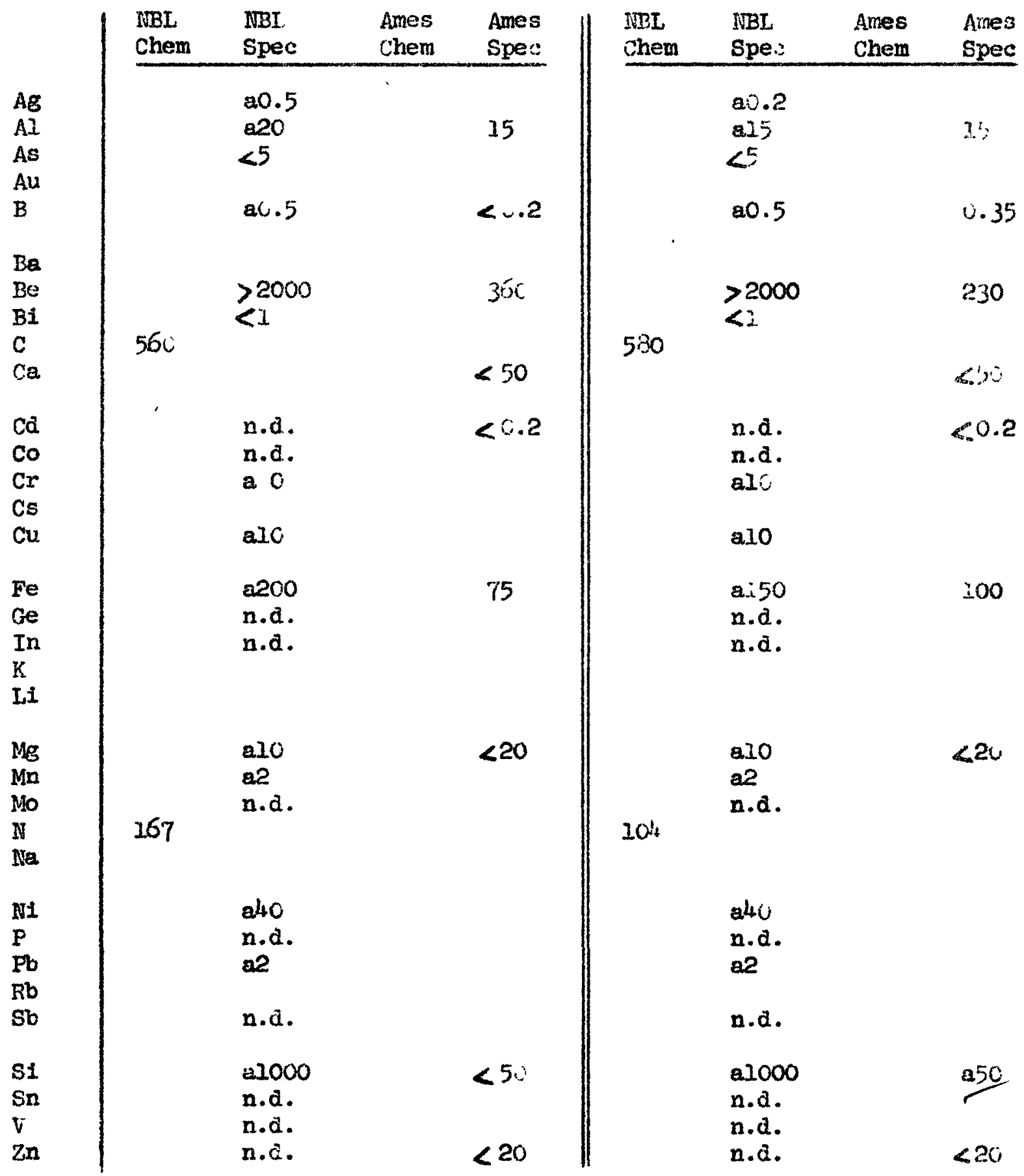


$2+635$

ix-639

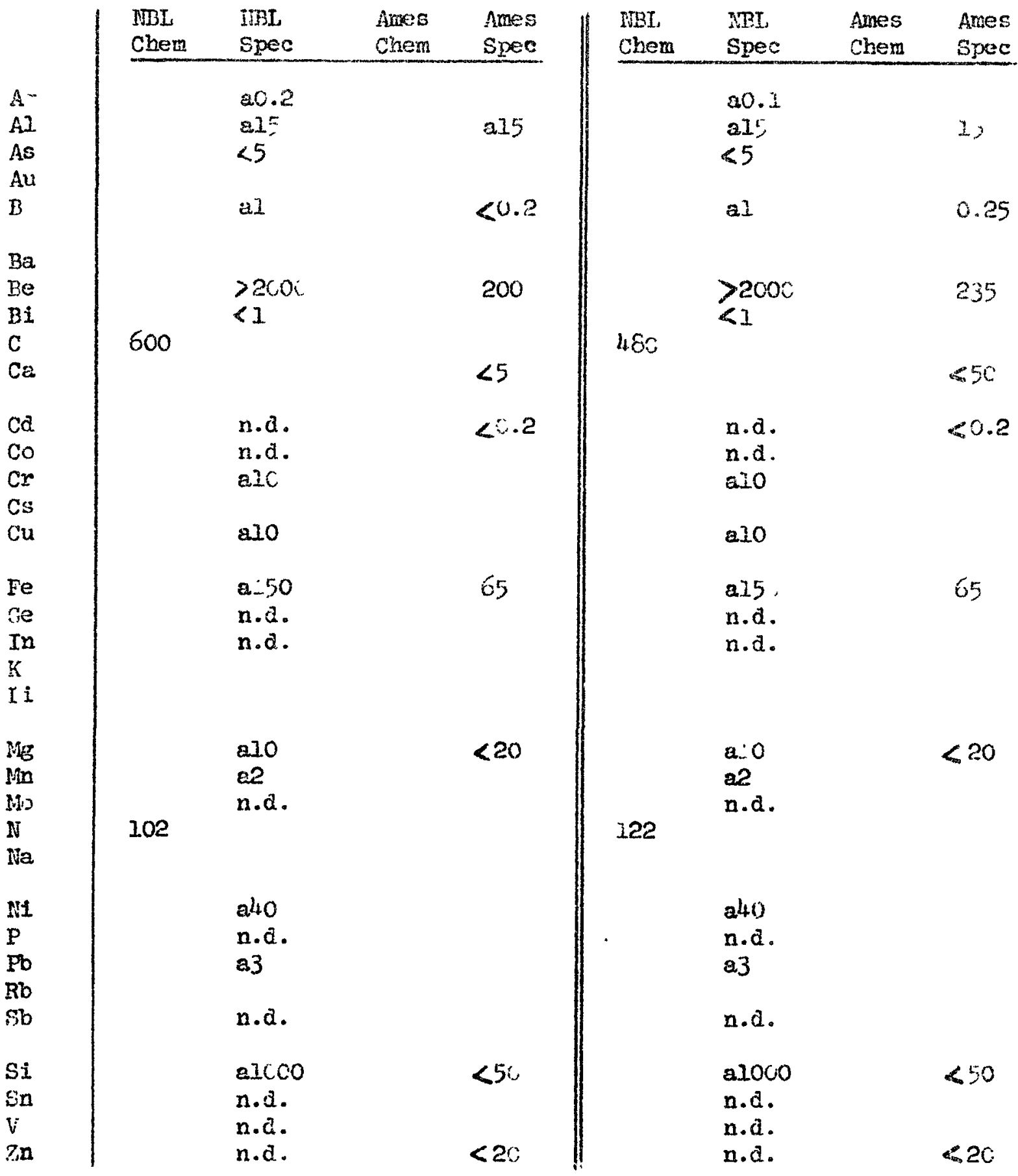




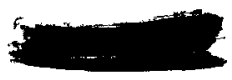

$x+x-606$

$3 x-55:$

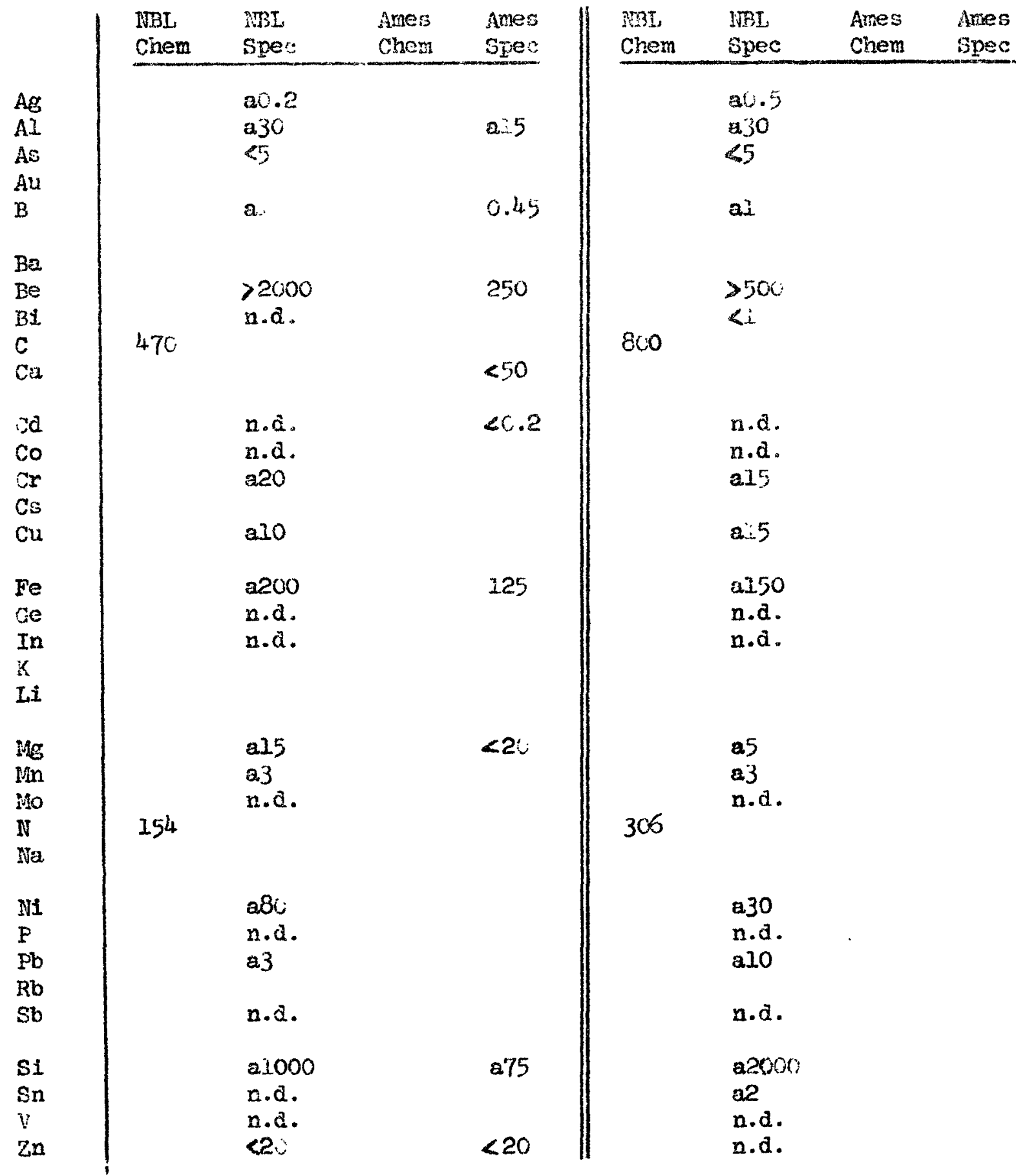




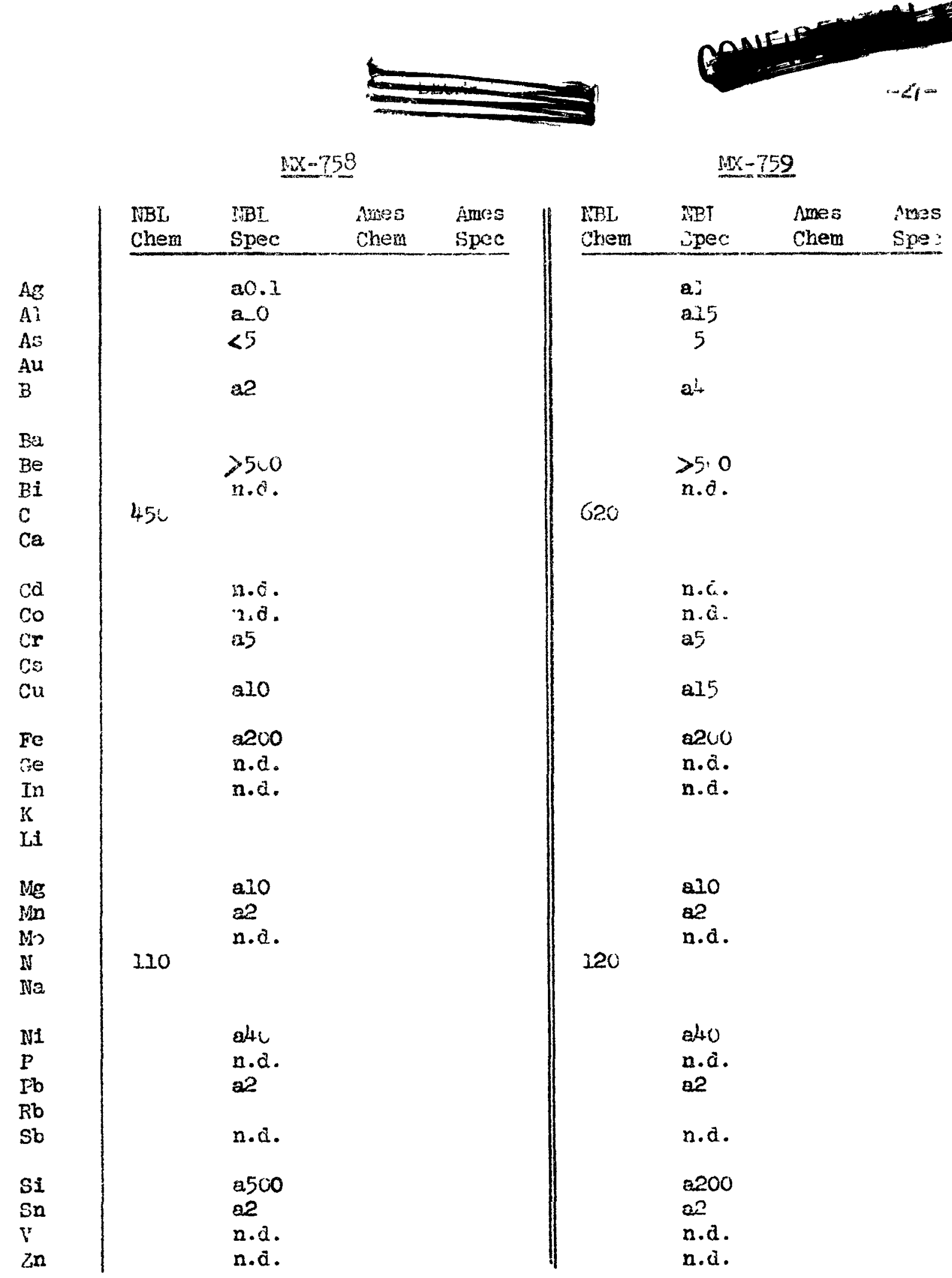

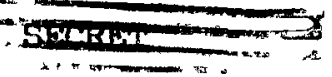




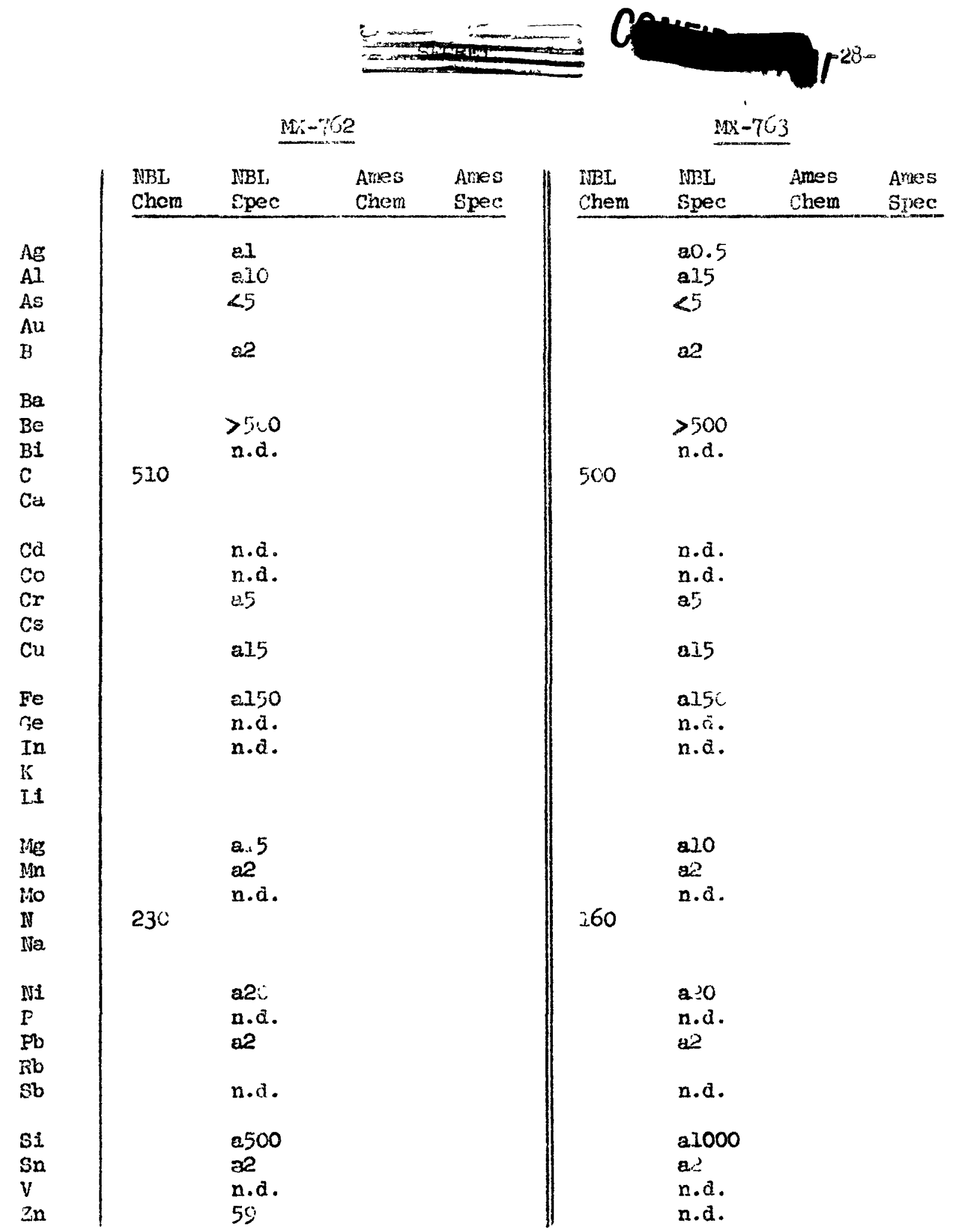

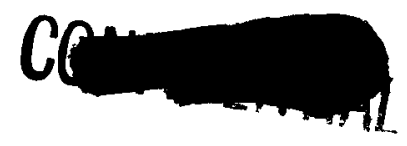




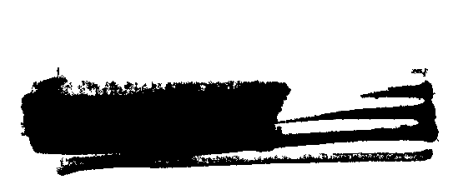

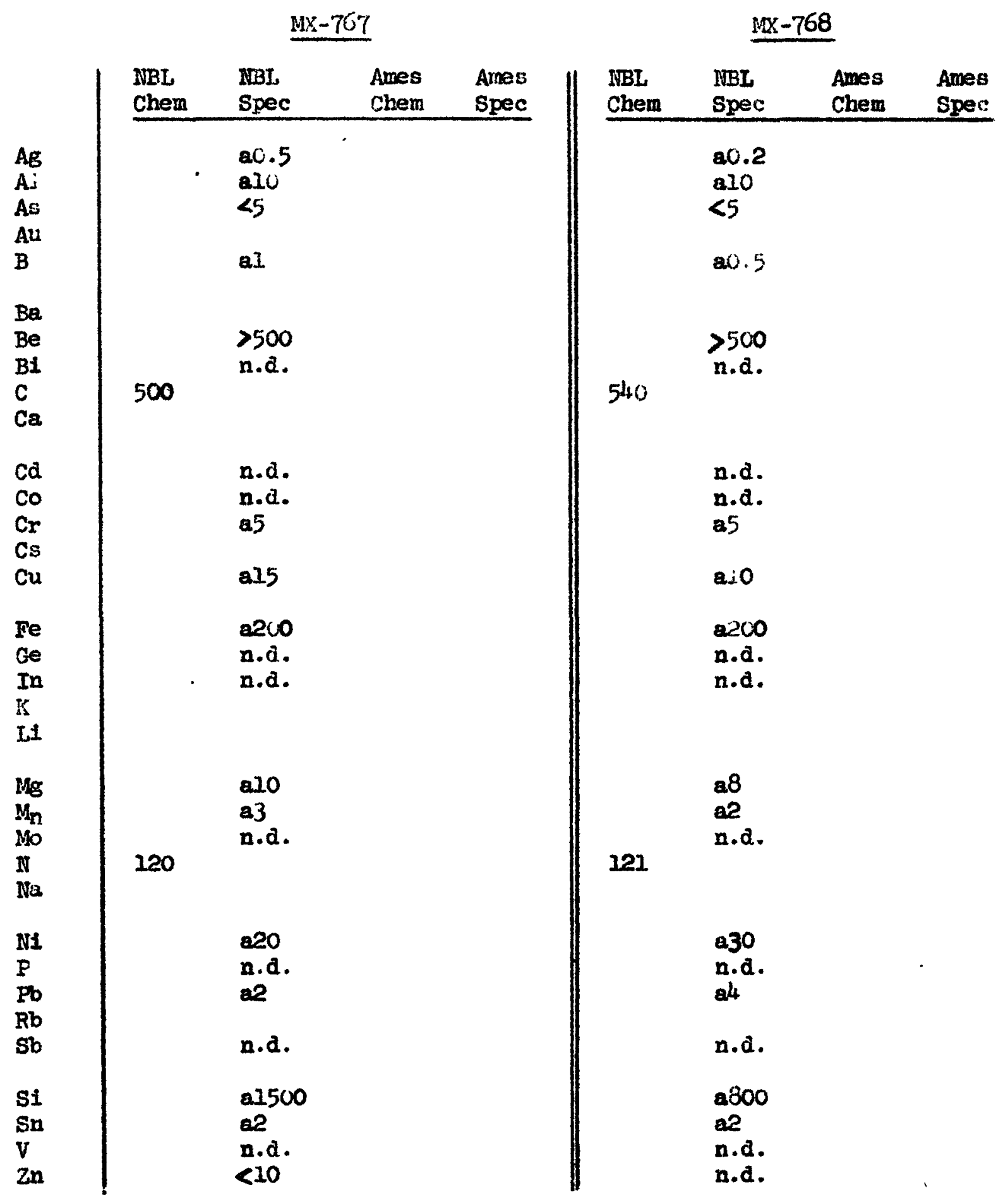

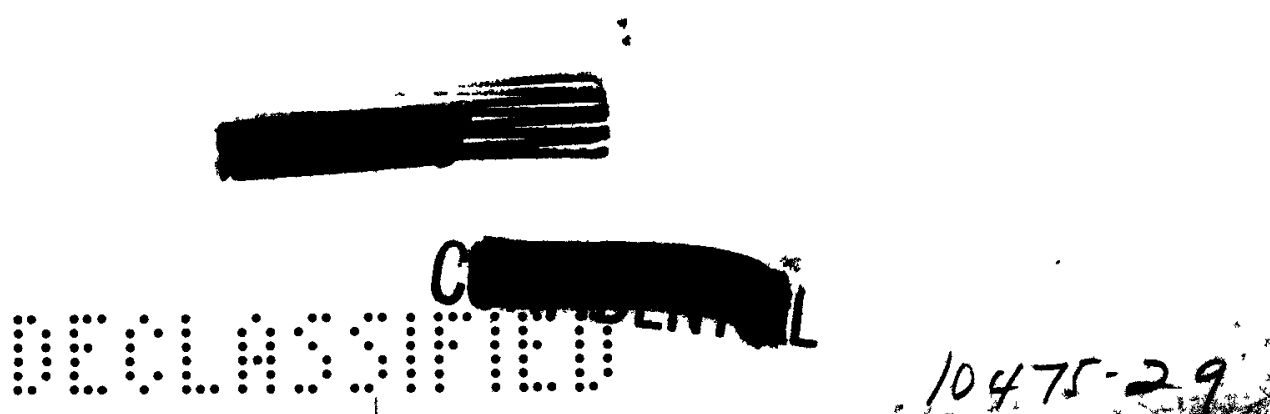




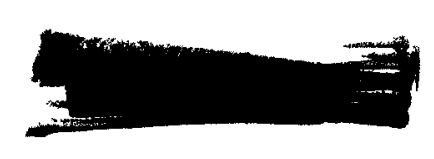

gomelatitils

$-30-$

$30 x-770$

$M x-775$

\begin{tabular}{|c|c|c|c|c|c|c|c|c|}
\hline & $\begin{array}{l}\text { IIBL } \\
\text { Chem }\end{array}$ & $\begin{array}{l}\text { MBL } \\
\text { Spec }\end{array}$ & $\begin{array}{l}\text { Ames } \\
\text { Chem }\end{array}$ & $\begin{array}{l}\text { Ames } \\
\text { Spec }\end{array}$ & $\begin{array}{l}\text { NBI } \\
\text { Chem }\end{array}$ & $\begin{array}{l}\text { NBLL } \\
\text { Spec }\end{array}$ & $\begin{array}{l}\text { Ames } \\
\text { Chem }\end{array}$ & $\begin{array}{l}\text { Ames } \\
\text { Spec }\end{array}$ \\
\hline $\begin{array}{l}\mathrm{Ag} \\
\mathrm{Al} \\
\mathrm{As} \\
\mathrm{Au} \\
\mathrm{B}\end{array}$ & & $\begin{array}{l}20.2 \\
2.10 \\
<5 \\
21\end{array}$ & & & & $\begin{array}{l}20.4 \\
210 \\
<5 \\
20.2\end{array}$ & & \\
\hline $\begin{array}{l}\mathrm{Ba} \\
\mathrm{Be} \\
\mathrm{BI} \\
\mathrm{C} \\
\mathrm{Ca}\end{array}$ & 520 & $\begin{array}{l}>500 \\
\text { n.d. }\end{array}$ & & & 560 & $\begin{array}{l}>500 \\
\text { n.d. }\end{array}$ & & \\
\hline $\begin{array}{l}\mathrm{Cd} \\
\mathrm{Co} \\
\mathrm{Cr} \\
\mathrm{Cs} \\
\mathrm{Cu}\end{array}$ & & $\begin{array}{l}\text { n.d. } \\
\text { n.d. } \\
\text { a5 } \\
\text { a10 }\end{array}$ & & & & $\begin{array}{l}\text { n.d. } \\
\text { n.d. } \\
\text { a5 } \\
\text { alo }\end{array}$ & & \\
\hline $\begin{array}{l}\text { Fe } \\
\text { Ge } \\
\text { In } \\
\text { K } \\
\text { Ii }\end{array}$ & & $\begin{array}{l}\text { a200 } \\
\text { n.d. } \\
\text { n.d. }\end{array}$ & & & & $\begin{array}{l}\text { a250 } \\
\text { n.d. } \\
\text { n.d. }\end{array}$ & & \\
\hline $\begin{array}{l}\text { ME } \\
\text { Mo } \\
\text { Mo } \\
\text { Na }\end{array}$ & 123 & $\begin{array}{l}a 8 \\
a 2 \\
\text { n.d. }\end{array}$ & & & 133 & $\begin{array}{l}a 8 \\
\text { a.3 } \\
\text { n.d. }\end{array}$ & & \\
\hline $\begin{array}{l}\mathrm{NA} \\
\mathrm{P} \\
\mathrm{Pb} \\
\mathrm{Rb} \\
\mathrm{Sb}\end{array}$ & & $\begin{array}{l}\text { a30 } \\
\text { n.d. } \\
a 2 \\
\text { n.d. }\end{array}$ & & & & $\begin{array}{l}330 \\
\text { n.d. } \\
22 \\
\text { n.d. }\end{array}$ & & \\
\hline $\begin{array}{l}\text { Si } \\
\text { Sn } \\
\text { V } \\
\text { Zn }\end{array}$ & & $\begin{array}{l}\text { a.1000 } \\
\text { a2 } \\
\text { n.d. } \\
\text { n.d. }\end{array}$ & & & & $\begin{array}{l}\text { a1000 } \\
\text { a2 } \\
\text { n.d. } \\
\text { n.d. }\end{array}$ & & \\
\hline
\end{tabular}

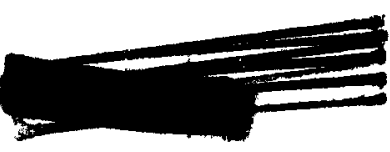

